\title{
Adaptive reuse of military establishments as museums: conservation vs. museography
}

\author{
K. Günçe ${ }^{1} \&$ D. Misırlısoy ${ }^{2}$ \\ ${ }^{1}$ Eastern Mediterranean University, Faculty of Architecture, Cyprus \\ ${ }^{2}$ Politecnico di Milano, Faculty of Architecture, Italy
}

\begin{abstract}
The preservation of historic buildings is important since they are social and cultural evidence of the past. In their lifetime, historic buildings may lose their function and become abandoned. Adaptive reuse is a way for a historic building to survive by changing the function according to the needs of its region.

Museography is a field that fundamentally contributes to the collection, conservation and protection of a significant part of the movable cultural heritage. It comprises the methods and techniques related to the practical function of museums.

In a museum the most important concern is the organization of displays, the use of light, circulation in the place and accessibility. If a museum is in an architectural heritage, this situation may create challenges both for designers and museographers since important concerns for conservation and museography should be taken into consideration together. Military establishments were mainly constructed for defence purpose including castles, military posts and towers; however, the reason of construction, forms similar characteristics among military buildings such as introverted organization and solid facades.

The aim of the study is to question the success of the adaptive reuse projects in terms of appropriateness of the museum function in a military establishment both in a conservation approach and museography approach. The study is a comparative research. Two selected castles will be compared in terms of use of military establishments as museums. The castles are selected from two different countries: Sforzesco Castle in Milan, Italy and Kyrenia Castle in Kyrenia, Cyprus which was used as castles before and are now converted to museums. The buildings are evaluated in two parts with the defined criteria: firstly in terms of conservation principles and secondly in terms of museography. In order to
\end{abstract}


question the success of a museum in a historic building, it is not enough to evaluate it only in terms of conservation principles. The concerns about museography are also crucial. The solutions depend on the creativity of the designer; however the correct approach is the collaboration of designer and museographer.

Keywords: conservation, adaptive reuse, defence heritage, museography.

\section{Introduction}

Historic buildings represent crucial resources in terms of aesthetic, culture and economy. The design and construction of new buildings have started to decrease at the end of the second millennium. On the other hand, interventions to existing buildings are becoming more important (Cramer and Breitling [8]). 40 percent of construction in Central Europe is adaptation of historic buildings rather than demolishing them and construct the new ones (Schittich [19]). Adaptive reuse strategies help to promote development of sustainable built environment (Conejos et al. [7]). Re-use of buildings and adaptation has become an increasing trend within the built environment. Extending the life of a building through reuse can lower material, transport and energy consumption and pollution. It makes a significant contribution to sustainability (Bullen and Love [4]).

On the other hand, heritage conservation provides economic, cultural and social benefits to urban communities. The role of building conservation has changed from preservation to being part of urban regeneration and sustainability (Bullen and Love [5]). According to the Department of Environment and Heritage (DEH [10]) "heritage buildings provide a valuable notice of the past and give character to communities and therefore should be conserved for future generations".

\section{Theoretical background}

There are reasons why buildings become redundant: from changing economic and industrial practices, demographic shifts, increasing cost of upkeep or maintenance and primarily because they are no longer suited for the function they were being used for and viable new use has not been identified (Orbaşli [18]). Adaptive reuse is a method for making these buildings alive again. The Department of Environment and Heritage [10] defines adaptive re-use as "a process that changes a disused or ineffective item into a new item that can be used for a different purpose". It is often described as a "process by which structurally sound older buildings are developed for economically viable new uses (Austin [1])".

Mostly, buildings change their use through their lifetime. Making changes to a building to accommodate a new use is often a means to provide the continued usefulness of an architectural heritage. However, the appropriateness of the new use to the historic building and its integrity should be considered (Orbaşl1 [18]).

Adaptation of a building is the process of transforming an existing building to accommodate new uses (Brooker and Stone [3]). These adaptations can differ 
from one case to another. As Douglas [11] determines: "It means any intervention go beyond maintenance to change its capacity, function or performance." It includes alteration, conversion, extension and refurbishment.

\subsection{Conservation}

Burra Charter [2], defines conservation as: "All the process of looking after a place so as to retain its cultural significance. It includes maintenance and may according to circumstances include preservation, restoration, renovation and adaptation and will commonly be combination of more than of those". Conservation is the process of understanding, safeguarding and, if it is needed, maintaining, repairing, restoring and adapting historic buildings to preserve its cultural significance (Orbaşl1 [18]). However, the understanding of conservation has now changed when compared with the previous resources. Contemporary conservation concept is a more complex activity today. Just a few decades ago, it was much simpler (Vinas [22]). Modern conservation is characterized by the fundamental change of values in contemporary society (Jokilehto [15]).

In recent decades, people are becoming more conscious of the unity of human values and regard ancient monuments as a common heritage; additionally, the main responsibility to preserve them for future generations is recognized. It is our duty to safeguard their authenticity (ICOMOS [14]). Modern conservation does not mean a return the architectural heritage to the past. It demands courage sustainable human development within the reality and the potential of existing cultural, physical and environmental resources (Jokilehto [15]).

There are international charters and standards which guide us in conservation and adaptation process. They define criteria for the conservation of historic buildings, additions and level of the interventions. Venice Charter is one of the important charters and there are two articles for the new additions to historic buildings. Article 5 states that "The conservation of monuments is always facilitated by making use of them for some socially useful purpose. Such use, is therefore, desirable but it must not change the lay-out or decoration of the building. It is within these limits only that modifications demanded by a change of function should be envisaged and may be permitted".

In Burra Charter that is another crucial one it is defined that: "Conservation is based on a respect for the existing fabric and should involve the least possible physical intervention. It should not distort the evidence provided by the fabric. The traces of additions, alterations and earlier treatments on the fabric of a place are evidence of its history and uses. Conservation action should tend to assist rather than to impede their interpretation. New construction work, including infill and additions, may be acceptable, provided: it does not reduce or obscure the cultural significance of the place".

On the other hand, The Secretary of the Interior's Standards for Rehabilitation discussed that: "New additions, exterior alterations, or related new construction shall not destroy historic materials that characterize the property. The new work shall be differentiated from the old and shall be compatible with the massing, size, scale, and architectural features to protect the historic integrity of the property and its environment". 


\subsection{Museography}

Museum making is challenging, creative, complex and collaborative in the twenty-first century. It also deals with many professional practices from curation to design and from architecture to theatre and film. In the twenty-first century, the museum design is multidisciplinary, multifaceted and as complex as the variety of exhibitions (Macleod et al. [17]).

In museum design there are two important terminologies: museology and museography; these terms are always mixed with each other. 'Museology' is broadly used as a term of reference based on ideas of theoretical inquiry. 'Museography' is museology's more down-to-earth, practically minded sibling (Grewcock [13]). The critical and theoretical examination of the museal field is museology, whereas the practical aspects is museography.

Museology can be simply defined as the study of museums, their history and underlying philosophy, their unspoken aims and policies, their educative or political or social role (Vergo [21]). On the other hand, museography is a field that fundamentally contributes to the collection, conservation and protection of a significant part of the movable cultural heritage. Museography, basically, deals with practical aspects of the museums like accessibility to the museum, circulation, display of art pieces, aspects of the museum lighting, climate control, collection security and flexibility.

\subsection{Conservation vs. museography}

In a museum, aspects like organization of displays, circulation or lighting in a museum are important aspects for a successful exhibition design. Additionally, when a museum is in an architectural heritage, this situation may create more challenges both for designers and museographers since important concerns for conservation and museography should be taken into consideration together.

Military establishments were mainly constructed for defence purpose including castles and bases; so the reason of construction forms similar characteristics among military buildings such as introverted organization and solid facades. For these reasons, generally castles are preferred converted into museums.

Although museum functions are appropriate for the castles, there are many aspects of conservation and museography which creates challenges for the designer. There could be a conflict between aspects of conservation and museography in the adaptation process of the architectural heritage. These aspects are defined in Table 1.

Museum designs are not easy tasks. Additionally, when the museum is in a historic building, the challenges are doubled since museography aspects should be considered in combination with conservation aspects. In a museum, one of the most important aspects is accessibility. The legibility of the entrance and accessibility of the building from the city should be well defined. The circulation route in the exhibition spaces should be well designed; on the other hand, protection of the art pieces should be provided. The appropriate lighting should 
Table 1: Conservation vs. museography.

\begin{tabular}{|l|l|}
\hline \multicolumn{2}{|c|}{ ASPECTS OF MUSEOGRAPHY AND CONSERVATION } \\
\hline \multicolumn{1}{|c|}{ MUSEOGRAPHY } & \multicolumn{1}{c|}{ CONSERVATION } \\
\hline Accessibility & Location and integration with the city \\
\hline Circulation & Appropriateness of the new function \\
\hline Organization of the display & Respect buildings history \\
\hline Aspects of museum lighting & Respect to originality of the building \\
\hline Climate control & Reversibility of the additions \\
\hline Collection security & Legibility of additions \\
\hline Flexibility for temporary exhibitions & Use of appropriate materials \\
\hline
\end{tabular}

be used for exhibits. These could be natural or artificial lighting; however, natural lighting should not be reflected directly on the art pieces so that not to harm them. Correct room temperature should also be supplied for the protection of exhibits.

On the other hand, building should be integrated with the city. For a successful adaptation, the heritage building should not be accepted as a single object; its surrounding and neighbourhood should also be considered. The new function of the building should be appropriate not to harm of the architectural heritage. New interventions should respect the building history and originality of the building. As indicated in different charters, new additions should be reversible, distinguishable. Appropriate materials should be used to preserve the authenticity of the building.

\section{Evaluation of the case studies}

\subsection{Reuse of military establishments}

Latham [16] divides military establishments into two groups as castles and bases. Castles are monuments that must be preserved since they represent a sense of identity, national pride and bearing a message of the oppression. The only way to sustain these monuments are re-functioning since they already lost the original function. However, the problem is to select the most appropriate function according to the structural and formal characteristics of the monuments.

In the case of used or recently occupied castles there is continuity to be found in their use, the building fabric acting as a museum backdrop, heightened with an extensive range of artefacts to conserve and display. However, there is an intense conflict between the preservation of the original structure and all its later interventions (Latham [16]).

Another type of military establishments are bases which are used for security reasons. These structures mostly are not magnificent and unique buildings like castles, but they symbolise major conflicts. Bases are generally huge complexes which comprises working institutions, accommodation to thousands of personal with all the amenities of community support that you would expect to find in a small town. Reuse of structures that is so large, requires not a building examination, but a holistic approach (Latham [16]). 


\subsection{Case study selection}

As the case studies, two castles have been selected from two different countries to be analyzed: Sforzesco Castle in Milan, Italy and Kyrenia Castle in Kyrenia, Cyprus. Both case studies was used as castle before and now converted to museum. These two castles are selected because of the common points. Both are located in city center of important cities, in a strategic location.

Today, Milan is the main industrial, commercial and financial centre of Italy. Additionally, it is a major capital for business, fashion and design. Sforzesco Castle is located in the city center of Milan, connecting the Piazza del Duomo and Parco Sempione with each other. It is located in the most crowded tourist attraction point of the Milan.

Kyrenia Castle is located in Kyrenia city, which is one of the most important cities of Cyprus in terms of tourist attraction. It is located next to the harbour, which is full of cafes, bars and restaurants used by both local people and tourists. Both of the buildings now converted into museums. However, the success of the reuse will be discussed in terms of conservation and museography by comparison method.

\subsection{Sforzesco Castle}

The Castello Sforzesco is one of the crucial symbols of Milan. Construction of the fort began under the rule of the Visconti family in the mid-century. Its construction began shortly after the mid-14th century and extended until the early 20th. Over its long history, the Castle has been used for various functions: it was built as a fortress, but was subsequently transformed into the magnificent palace of the dukes of Milan, first the Viscontis and then the Sforza. For over six centuries, the Castello Sforzesco has witnessed the events the events of Milanese history and become one of the city's most symbolic monuments (Carmignani [6]).

Previously restored by Luca Beltrami and Gaetano Moretti (1893-1906), the musuem's most recent restoration and reorganization was carried out by studio BBPR in two stages: in 1954-56 the area around the Ducal courtyard (Figure 1f) was remodelled and in 1963 the rooms flanking the Cortile della Rocchetta (Figure 1e) restored (Dal Co and Polano [9]).

The Municipality of Milan acquired ownership of it at the end of the 19th century and began a restoration to return it to its ancient splendour and use it as the headquarters for major museum institutions. Today the Castle is a prestigious museum site and can boast work from the national and international artistic heritage in its collections, such as the famous Pieta Rondanini, Michelangelo's final masterpiece (Carmignani [6]). The Castle houses four different museum as shown below and additionally an archive and a library.

- Archeological museums.

- Museums of ancient art.

- Museums of decorative arts.

- Museum of musical instruments. 


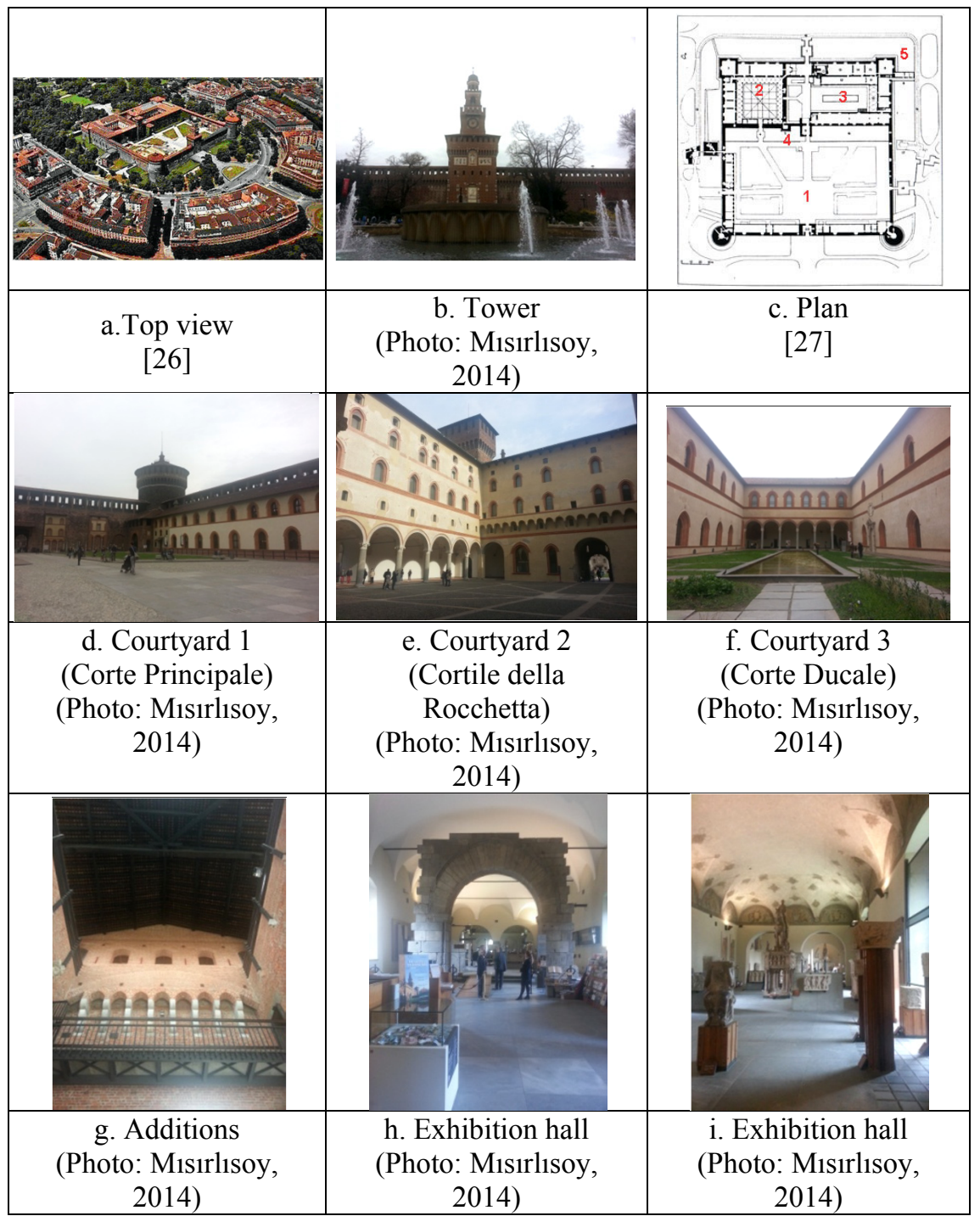

Figure 1: Visual media of Sforzesco Castle.

\subsection{Kyrenia Castle}

Kyrenia Castle, which dominates the old harbour, is the most complete castle on the island out of three important castles in Cyprus. It is thought to have been built by the Byzantines around 700 to protect the town against Arab raids; however, it was built over an older Roman structure. In 1191, Guy de Lusignan seized the castle from the self-proclaimed king of Cyprus, Isaac Commenos. The Castle played an important role in Lusignan period and it underwent a lot of 
changes due to restoration work. The castle was further extended by Venetians and today's look of the castle is the Venetian structure [28].

The main features of the exterior are the huge round towers built by the Venetians about $1540 \mathrm{AD}$. This was a period of history in which gunpowder, cannon and the use of artillery were being developed for the first time in military operations. In this period, huge high walls with round towers at the corners were built since it is more difficult to demolish a round tower than a square tower with the cannon fire. Then, this invention causes a new type of military architecture arose in the 16th century (Dreghorn [12]).

The castle was used as various functions before. It is used as a prison at various times during the Lusignan period, and by the British, it is used in their administration. To the east of the courtyard there are two archaeological exhibits. The first is the Tomb-finds Gallery (Figure 2h), comprising three major exhibits spanning the Neolithic, Bronze Age and Hellenistic to Byzantine periods. Next door, the Shipwreck museum (Figure 2g) displays a cargo boat which sank just off Kyrenia some 2300 years ago and is the oldest shipwreck known [28]. The Ancient Shipwreck Museum at Kyrenia Castle was officially opened in 1976 (Dreghorn [12]). It houses to an old trading ship, along with its cargo, which sailed the Mediterranean Sea during the time of Alexander the Great. The vessel and cargo were raised from the bed of the ocean, and now form a fascinating historical exhibit at the Ancient Shipwreck Museum [23]. The Castle is now converted into archeological museum:

- Shipwreck museum.

- Tomb-finds gallery.

\subsection{Evaluation of case studies}

Sforzesco Castle has a pure rectangular shape, which is divided into three parts as Corte Principale, Rocchetta and Corte Ducale (Figure 1c). Castle acts as a connection of two important gathering places for Milan, which is Piazza del Duomo and Parco Sempione. It provides access from the Duomo to park since there is free access to the courtyards for the ones, who does not want to visit the museums as well. Castle acts also as a meeting point for the local people and tourists. It is well integrated to the city with its fascinating landscape.

Sforzesco Castle had been bombed during the Second World II and damaged seriously. Some parts of the roof had been collapsed and renovated by BBPR during restoration process, also the tower for the entrance was demolished and rebuilt. Although the roof additions, circulation routes and exhibition panels are distinguishable additions with contemporary material, the tower is a replica of the original and is not legible. Article 12 in ICOMOS [14] states that: "Replacements of missing parts must integrate harmoniously with the whole, but at the same time must be distinguishable from the original so that restoration does not falsify the artistic or historic evidence". 


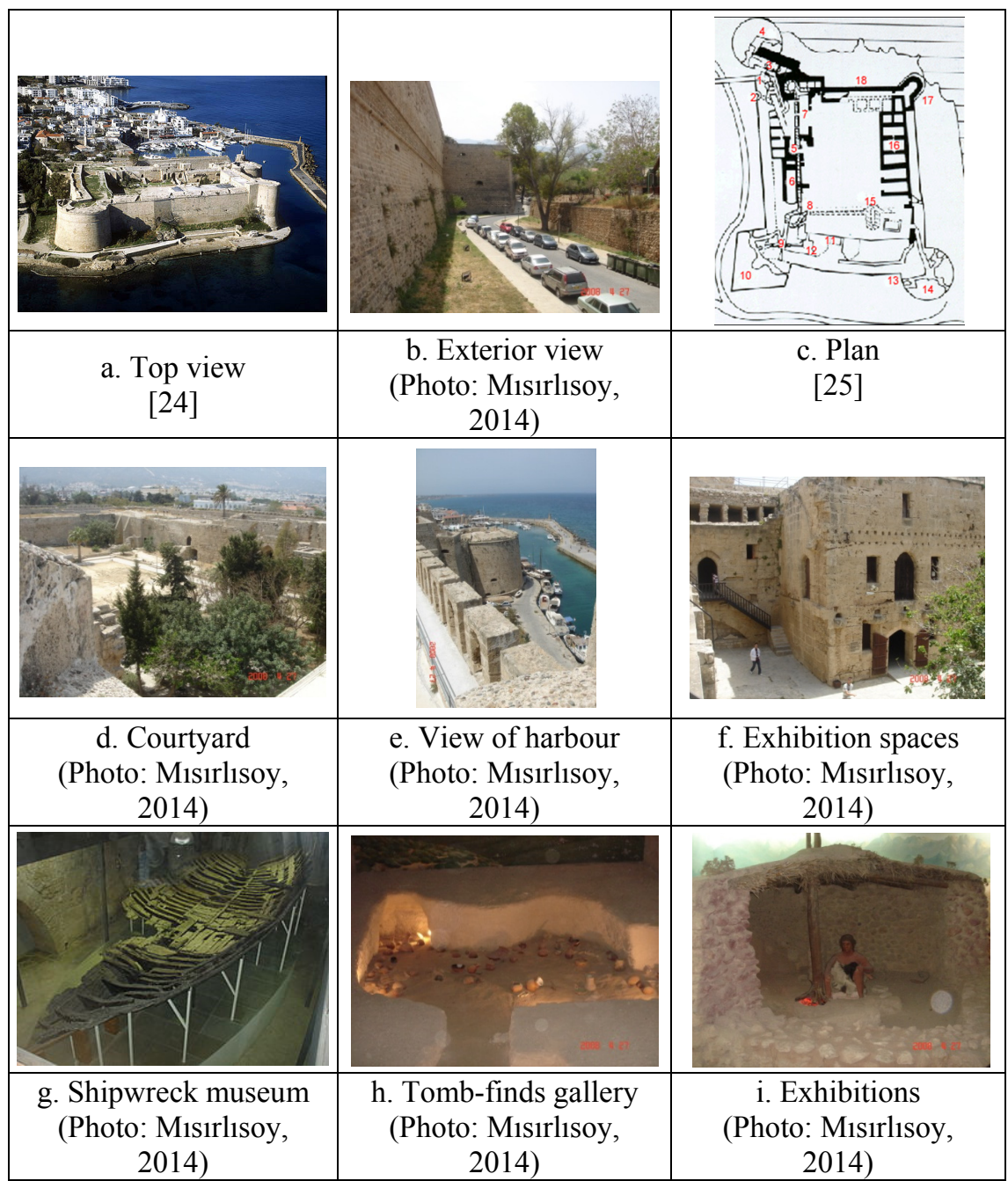

Figure 2: Visual media of Kyrenia Castle.

The accessibility to the castle is easy to perceive and although the museum is huge and consist of four museum parts, the circulation paths of the exhibitions are well-defined. The exhibitions are fixed and not flexible since there are other parts for temporary exhibitions. For the lighting of the art pieces, both natural and artificial light is used; however the use of natural light is more and this can be quite dangerous for the unique art pieces. The sunlight should be well controlled for the protection of the exhibits. The security of the collections are quite successful in terms of exhibit units.

On the other hand, Kyrenia Castle has an organic shape with four bastions in each corner, having a huge courtyard in the middle. The Castle is located in the 
city center, next to the Kyrenia harbour, which is one of the most important tourist attraction point of the city. Although the advantages of the location, castle is not well integrated with the city. All the museums in the Kyrenia castle are permanent exhibitions and this situation causes the number of the local visitors to decrease. Local people visit museum once and never go again. Although there is some activities is organized in the courtyard like some music concerts, courtyard is so huge and not well-designed, these activities is not enough to survive the castle from the lack of a living function. Museum should be supported with the temporary art exhibitions and activities to attract local people as well.

The museum opened in 1976 and after that time there were no intervention to the museum. Although the old history of the structure is well preserved until today, the design of the museum should be re-thought. There had been just some rehabilitation work during restoration and there are no later additions to the structure.

Kyrenia Castle, has an only access from the harbour with a bridge; however it is not a visible and welcoming entrance. The Castle has a solid facade without openings since it was constructed as a protection purposes from enemies. This creates problems for the structure as a museum function. Since the castle has a solid facade and the number of the openings are limited, in general artificial lighting is used as lighting the exhibits. Although the castle is quite big, the exhibitions are not enough when compared with the scale of the building. Circulations are not well-defined and collection security is not enough.

\section{Conclusion}

Adaptation of an architectural heritage is a challenging process. Values, physical characteristics and potentials of the building should be well analyzed. There is a tendency to use castles as museums because of the physical characteristics. Castles usually build for protection purposes, so facades are solid with limited openings and plan layout has an introverted organization, generally with a courtyard in the middle. Although museum function is appropriate for the castles physically, conservation and museography aspects should be considered together.

In general, both of the castles analyzed are successful in terms of conservation aspects. However, in order to sustain the new function of the building, it should be usable for both local people and tourists. Especially, in Kyrenia Castle museography issues should be rethought and existing museums should be supported by other temporary exhibition and activities. On the other hand, in Sforzesco Castle, the use of direct natural lighting on the art pieces should be rethought. Another important criticism to both cases is that accessibility to the building by disabled people were ignored in both adaptations.

In order to question the success of a museum in a historic building, is not enough evaluate it only in terms of conservation principles. The concerns about museography is also crucial in order to sustain the proposed function of the 
building. The solutions depend on the creativity of the designer; however the correct approach is the collaboration of designer and museographer.

\section{References}

[1] Austin, R.L., Adaptive Reuse: Issues and Case Studies in Building Preservation, Van Nostrand Reinhold Company: New York, 1988.

[2] Australia ICOMOS, Burra Charter, The Charter for Places of Cultural Significance [online]. Available from: http://australia.icomos.org/ wpcontent/uploads/BURRA_CHARTER.pdf, [Accessed in June 2012], 1999.

[3] Brooker, G. \& Stone S., Context and Environment, Ava Publishing: Switzerland, 2008.

[4] Bullen, P.A. \& Love, P.E.D., Residential regeneration and adaptive reuse: learning from the experiences of Los Angeles, Structural Survey, Vol. 27 No. 5, pp. 351-60, 2009.

[5] Bullen, P.A. \& Love, P.E.D., Adaptive reuse of heritage buildings, Structural Survey, Vol.29 Iss: 5 pp. 411-421, 2011.

[6] Carmignani, M., The Castello Sforzesco of Milan, Skira Guide: Milan, 2008.

[7] Conejos, S., Langston, C., \& Smith, J., AdaptSTAR model: A climatefriendly strategy to promote built environment sustainability, Habitat International, pp. 1-9, 2012.

[8] Cramer, J., \& Breitling S., Architecture in Existing Fabric, Birkhauser: London, 2007.

[9] Dal Co, F. \& Polano, S., The 20th century architecture and urbanism: Milano, A+U Publishing: Japan. 1991.

[10] DEH, Adaptive reuse: Preserving our past, building our future. ACT: Department of Environment and Heritage, Commonwealth of Australia, 2004.

[11] Douglas, J., Building Adaptation, Butterworth-Heinemann Publishing: London, 2006.

[12] Dreghorn, W., A guide to the antiques of Kyrenia, Cyprus Turkish Tourism Enterprises: Kyrenia, 1982.

[13] Grewcock, D., Doing Museology Differently, Routledge: London, 2013.

[14] ICOMOS, Venice Charter, International charter for the conservation and restoration of monuments and sites, Available from: http://www.icomos.org/charters/venice_e.pdf [Accessed in June 2012], 1964.

[15] Jokilehto, J., A History of Architectural Conservation, ICCROM: Italy, 1999.

[16] Latham, D., Creative re-use of buildings Volume II, Donhead Publishing: London, 2000.

[17] Macleod S., Hanks, L.H., \& Hale, J., Museum making: Narratives, Architectures, Exhibitions, Routledge: London, 2012. 
[18] Orbaşl1, A., Architectural Conservation, Blackwell Publishing: London, 2008.

[19] Schittich, C., In Detail Interior Spaces, Birkhauser: Berlin, 2003.

[20] The Secretary of the interior's standards for rehabilitation. Available from: http://www.nps.gov/hps/tps/standguide/rehab/rehab_standards.htm. [Accessed in June 2012], 1979.

[21] Vergo, P., New Museology, Reaktion: London, 1989.

[22] Vinas, S.M., Contemporary Theory of Conservation, Elsevier Butterworth-Heinemann: Oxford, 2005.

[23] Kyrenia Castle, www.allaboutkyrenia.com.

[24] www.soniahalliday.com.

[25] www.cypnet.co.uk.

[26] www.guideuropa.eu.

[27] www.italianluvaffair.com.

[28] Kyrenia Castle, www.whatson-northcyprus.com. 